\title{
International Entrepreneurial Orientation: Exploring the Brazilian Context
}

\author{
Ricardo Raats, Patricia Krakauer
}

\section{A B S T R A C T}

Objective: To explore the practises that characterise the International Entrepreneurial Orientation (IEO) of SMEs who endeavour to reach foreign markets from emerging economies.

Research Design \& Methods: The multiple case study method analysed data collected through interviews and examined with the support of NVIVO software. Panels provide visualisation of entrepreneurial postures, while a final description supports the explanation of four companies' context.

Findings: The combination of IEO dimensions assumes a distinct synergistic effect in different companies' internationalisation moments. The study suggests that competitive aggressiveness is confused as being part of proactivity in that country context, as the autonomy dimension was not utilised sufficiently by the companies.

Implications \& Recommendations: Resources such as networks, licenses, and certifications are competitive advantages that encourage forceful entry despite organisational constraints. Future research can investigate concepts of co-creation to bring new insights into the international development of companies and products.

Contribution \& Value Added: To distinguish how entrepreneurial organisations with autonomy constraints succeed by showing competitive aggressiveness as critical determinants to entering new foreign markets with innovative products.

\begin{tabular}{lll}
\hline Article type: & $\begin{array}{l}\text { research article } \\
\text { entrepreneurship orientation; international entrepreneurship; } \\
\text { Keywords: }\end{array}$ & $\begin{array}{l}\text { emerging economy; international entrepreneurial orientation; SMEs; } \\
\text { internationalisation }\end{array}$ \\
JEL codes: & L26, F23 & \\
\hline Received: 30 September 2019 $\quad$ Revised: 6 January 2020 & Accepted: 10 January 2020 \\
\hline
\end{tabular}

Suggested citation:

Raats, R., \& Krakauer, P. (2020). International Entrepreneurial Orientation: Exploring the Brazilian Context. Entrepreneurial Business and Economics Review, 8(1), 51-69. https://doi.org/10.15678/EBER.2020.080103 


\section{INTRODUCTION}

The entrepreneurship and strategy literature indicate that entrepreneurial orientation (EO) improves skills and overall performance in organisations (Rauch, Wiklund, Lumpkin, \& Frese, 2009). Assuming that firms show different competences in aggressive environments (Wiklund \& Shepherd, 2005), scholars point to investigating SMEs' strategic organisational posture as a central element to outline these firms' profiles in international business (Sapienza, Autio, George, \& Zahra, 2006; Knight \& Kim, 2009).

In terms of internationalisation theories, there is extant literature that focuses on the entry stage, growth, and survival of companies in foreign markets as an opportunity-seeking behaviour (Coviello, McDougall \& Oviatt, 2011; Jones, Coviello \& Tang, 2011). Such trajectories, when intensified by entrepreneurial orientation, highlights SMEs internationalisation from both economics and management perspectives (Kuivalainen, Sundqvist, Saarenketo, \& McNaughton, 2012; Dai, Maksimov, Gilbert, \& Fernhaber, 2014). Different scholars argue that export market exploitation and exploration capabilities refer to the entrepreneur's abilities and resources (Birkinshaw \& Gupta, 2013), while others emphasise the more considerable influence of firm's capacities to acquire new overseas market (Lisboa, Skarmeas, \& Lages, 2011). When applied to international contexts, the most effective firms operate exploration and exploitation processes in a state of ambidexterity (Covin \& Miller, 2014), to investigate strategic decisions regarding their actions of international marketing (Kozlenkova, Samaha, \& Palmatier, 2014), allows firms to create specific capabilities and develop competitive advantages across national borders (Kazlauskaitè, Autio, Gelbūda, \& Šarapovas, 2015).

Regardless of a comprehensive theory of entrepreneurial internationalisation (Wach, 2015), Brazilian SMEs may offer insights on how EO manifests inside organisations going through market expansion. Their late international expansion (Amal \& Freitag Filho, 2010; Da Rocha, Mello, Pacheco, \& Farias, 2012), is interesting to study internationalisation processes in organisations from emerging economies (Boso, Oghazi, \& Hultman, 2017). In Latin America, the overall business environment remains a challenge; Brazil falls near the bottom of the GEM 2018/2019 Global Report rankings (48 out of 54). Macroeconomic deterrents partially explain why most firms that ventured abroad in the past did so solely by exports (Carneiro \& Brenes, 2014). Besides, current international competitors' presence in local markets defies the lack of a global mindset. With this background in mind, few studies investigated practises that characterise the International Entrepreneurial Orientation (IEO) in Brazilian SMEs (Freitas, Martens, Boissin, \& Behr, 2012; Martens, Lacerda, Belfort, \& Freitas, 2016; Tonial \& Rossetto, 2017).

The current study seeks to understand whether IEO supported four companies to identify and capitalise on air sports international markets (Slevin \& Terjesen, 2011). The article offers a qualitative approach through a multiple case study to appreciate the firms' entrepreneurial actions after they already achieved international entries (Zahra, Wright, \& Abdelgawad, 2014). Operationally, the narrative analysis justifies the use of theoretical sources in addition to a description of cases with the help of qualitative data analysis software (Short, Broberg, Cogliser, \& Brigham., 2010). In-depth interviews collected data by questionnaires to assess the owners' view of their firm-specific competitive advantages (Doz, 2011). Content analysis method supported the entrepreneurs' narrative inquiry and 
provided the basis for a display to show the differences in entrepreneurial outcomes (Paulus, Woods, Atkins, \& Macklin, 2017). In a slightly ambitious way, this study serves to communicate the results and the construct's applicability in recent international business research (Etemad, 2019; Wales, Gupta, Marino, \& Shirokova, 2019). The research question is how do International Entrepreneurial Orientation (IEO) gains ground in SMEs exporting from an emergent economy, to verify empirically whether the five dimensions - innovativeness, proactivity, risk-taking, competitive aggressiveness, and autonomy - apply and relate to companies with different levels of internationalisation. Herein follows an explanation of the qualitative methodology employed. The next section describes the theoretical framework consisting of the components developed for researching, followed by the data analysis of interviews. Last, we offer final discussion and conclusion.

\section{LITERATURE REVIEW}

Early definitions of IEO resumed the concept as the leveraging of strategies prepared to enter foreign markets (Knight, 2001). According to Knight and Cavusgil (2005), a firm's innovation and proactivity reflect an overall aggressiveness, as it brings about specific capabilities needed for successful internationalisation. A more general argument is that the entrepreneur, firm, and environment are critical elements of the processes of entrepreneurial internationalisation (Jones \& Coviello, 2005). Scholars argue that opportunities are the result of firms' strategic adaptation regarding entrepreneurial knowledge and position in international networks (Freeman \& Cavusgil, 2007).

On the other hand, the combination of behaviours that aim to value opportunity creation as forms of innovative methods - risky and independent activities to overcome international competitors (Sundqvist, Kyläheiko, Kuivalainen, \& Cadogan., 2012) - qualify the concept of IEO as a construct only possible when high levels of innovativeness facilitate technological and marketing capabilities, directly promoting export sales level (Covin \& Miller, 2014). More recently, Boso et al. (2017) define IEO as processes that firms use to exploit entrepreneurial opportunities to create new products and services abroad. Concept development (Table 1) demonstrates that a large body of previous research used the original EO three-dimension scale of Miller/Covin and Slevin (1989) to measure firm performance (Covin \& Wales, 2012). However, as EO is inherently an exploratory orientation (Wiklund \& Shepherd, 2011), with a focus on pursuing new opportunities, it makes sense to operationalise IEO as a multidimensional construct with other examples of managerial orientations that enhance competitiveness by risk-taking actions in international contexts (Anderson, Kreiser, Kuratko, Hornsby, \& Eshima, 2015).

While the five-dimension scale of Lumpkin and Dess (1996) value similar entrepreneurial qualities, "being entrepreneurial" by the original 3D scale lacks consistency for the most recent conceptualisations, resulting in a different understanding of success in international contexts (Covin \& Lumpkin, 2011). Consequently, the aggregation of the dimensions of competitive aggressiveness and autonomy as necessary for the EO construct to exist in dynamic environments (Sundqvist et al., 2012; Boso et al., 2017) opens the conceptualisation of IEO to appreciate different sets of strategic managerial postures (Wach, 2015; Covin \& Wales, 2019). With that in mind, this study purposefully foregrounds the IEO construct as a multidimensional setting of five components, able to show entrepreneurial behaviour in organisations, by assuming that dimensions can vary in intensity and configurations, independently 
of the context (Miller, 2018; Wales et al., 2019). Therefore, following Wales (2016), the description of the dimensions was adapted to Brazilian companies' context to understand their entrepreneurial mechanism proposed for the investigation (Table 2).

Table 1. Selected definitions of IEO

IEO "reflects the firm's overall pro-activeness and aggressiveness in its pursuit of international markets" (Knight, 2001, p. 159)

IEO reflects "the firm's overall innovativeness and proactiveness in the pursuit of international markets. It is associated with innovativeness, managerial vision and proactive competitive posture" (Knight \& Cavusgil, 2005, p. 129)

IEO is "a set of attributes commonly acknowledged as helpful for overcoming obstacles in the internationalisation process" (Jones \& Coviello, 2005)

IEO "refers to the behaviour elements of a global orientation and captures top management's propensity for risk-taking, innovativeness, and proactiveness" (Freeman \& Cavusgil, 2007, p. 3)

IEO is "a set of behaviours associated with the potential creation of value with an emphasis on outperforming rivals across national borders" (Sundqvist et al., 2012, p. 205)

"IEO is not treated as a construct distinct from EO. Instead, 'international' is simply a context in which the EO phenomenon is explored" (Covin \& Miller, 2013, p. 14)

"IEO as the processes that firms use to exploit entrepreneurial opportunities to create new products and services abroad" (Boso et al., 2017, p.6)

Source: own elaboration based on Wach (2015).

Table 2. Dimensions of IEO

\begin{tabular}{|l|l|}
\hline Dimensions & Definitions \\
\hline Proactivity & $\begin{array}{l}\text { It is the perspective of leadership capable of anticipating demands in the search } \\
\text { for opportunities (Dess \& Lumpkin, 2005). }\end{array}$ \\
\hline Innovation & $\begin{array}{l}\text { It aims to develop new products, services, and processes through experimenta- } \\
\text { tion and creativity introduced by the organisation (Leite \& Moraes, 2015). }\end{array}$ \\
\hline Risk-taking & $\begin{array}{l}\text { Organisational tendency to act with caution versus boldness to achieve goals } \\
\text { (Martens et al., 2016). }\end{array}$ \\
\hline Autonomy & $\begin{array}{l}\text { Independent action responsible for the conceptualisation of the business from } \\
\text { early expansion until its establishment in international markets, supporting mar- } \\
\text { keting, licensing strategies and final products export (Freitas et al., 2012). }\end{array}$ \\
\hline $\begin{array}{l}\text { Competitive } \\
\text { Aggressiveness }\end{array}$ & $\begin{array}{l}\text { The effort of the organisation in overcoming competitors, overcoming threats, or } \\
\text { improving market position (Freitas et al., 2012). }\end{array}$ \\
\hline
\end{tabular}

Source: own elaboration based on Wales (2016).

To understand the capacity building of the studied companies, the resource-based view (RBV) served as a theoretical perspective for explaining the internationalisation of SMEs when EO drove strategic initiatives (Knight, 2001). Meanwhile, an innovative small business will not be entrepreneurial if it does not take risks or is not sufficiently proactive towards competitors and environment (Jones \& Coviello, 2005), as it will not be able to sustain such advantage without policies and procedures in place to exploit the full competitive potential of its resources and capabilities (Alvarez \& Barney, 2017). Moreover, EO may prove insufficient as a resource for competitive advantage unless embedded in the very processes of a firm (Martin \& Javalgi, 2016). Teece, Peteraf, and Leih (2016) define capabilities as "the key role of strategic management in adapting, integrating, and reconfiguring internal and external organisational skills, resources, and 
functional competencies to match the requirements of a changing environment," so the above theoretical developments suggest building a three-step process of international entrepreneurial orientation (Figure 1).

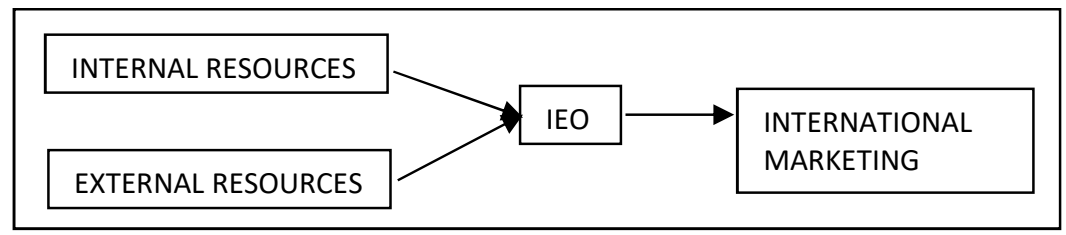

Figure 1. IEO from the Resource-Based View Source: own elaboration.

Given the above, SMEs can capitalise on international marketing strategies, because their managers' IEO deliberately support processes that focus on the search for information for competitive analysis and resource organisation (Swoboda \& Olejnik, 2016). Simultaneously, more than building capacities related to the aspects of product and market advantages, the collection of information is a fundamental element that underlies companies' decision about marketing differentiation strategies, building networks, or leveraging relationships (Alvarez \& Barney, 2017). Therefore, the IEO concept serves for the examination of organisational initiatives aimed at new markets and the introduction of new products (Table 3).

Table 3. Organisational Initiatives

\begin{tabular}{|c|l|l|}
\hline Concept & \multicolumn{1}{|c|}{ Processes } & \multicolumn{1}{|c|}{ Practices } \\
\hline \multirow{5}{*}{ IEO } & $\begin{array}{l}\text { Develop organisational compensation systems } \\
\text { for international partners }\end{array}$ & $\begin{array}{l}\text { The formation of distribution chan- } \\
\text { nels and commercial sales }\end{array}$ \\
\cline { 2 - 3 } & $\begin{array}{l}\text { Guarantee investments for prospecting and de- } \\
\text { veloping new international businesses }\end{array}$ & $\begin{array}{l}\text { Participation in events and commer- } \\
\text { cial networks }\end{array}$ \\
\cline { 2 - 3 } & $\begin{array}{l}\text { Create collaborations for identifying new oppor- } \\
\text { tunities and sales }\end{array}$ & $\begin{array}{l}\text { Involvement with institutions to } \\
\text { promote international business }\end{array}$ \\
\cline { 2 - 3 } & $\begin{array}{l}\text { Define resource allocation and risks involved in } \\
\text { innovations, product tests, and demonstrations }\end{array}$ & Market intelligence \\
\hline
\end{tabular}

Source: own elaboration based on Tonial and Rosseto (2014).

In this context, the study considered a series of managerial practises found in Brazilian literature (Table 4) concerning the adaptation to foreign competition in domestic and international markets, managerial capacity to innovate, and centralisation of decisions by the entrepreneur (Amal \& Freitag Filho, 2010; Da Rocha et al., 2012; Leite \& Moraes, 2015; Martens et al., 2016).

As IEO relies on the disciplines of entrepreneurship, international business, and strategic management (Wach, 2015), we first assembled the theoretical definitions of construct dimensions, next appraised the context of the construct, and then listed the managerial practises. Finally, based on Dess and Lumpkin (2005), we applied the semistructured questionnaire. 
Table 4. Elements of managerial practises

\begin{tabular}{|c|c|c|}
\hline \multirow{2}{*}{ Dimensions } & \multicolumn{2}{|r|}{ Management Elements } \\
\hline & Categories & Managerial Practices \\
\hline \multirow{4}{*}{ Proactivity } & Monitoring & Monitoring and market research of foreign markets \\
\hline & Anticipation & $\begin{array}{l}\text { Pioneering and tendency of the attack on the foreign } \\
\text { markets }\end{array}$ \\
\hline & Troubleshooting & $\begin{array}{l}\text { Participation and control as troubleshooting and oppor- } \\
\text { tunity planning }\end{array}$ \\
\hline & $\begin{array}{l}\text { Adaptability and flex- } \\
\text { ibility }\end{array}$ & $\begin{array}{l}\text { Availability and access to persons, resources, and equip- } \\
\text { ment necessary to have flexibility skills to meet foreign } \\
\text { market needs }\end{array}$ \\
\hline \multirow{4}{*}{ Innovation } & $\begin{array}{l}\text { Products for the ex- } \\
\text { ternal market }\end{array}$ & $\begin{array}{l}\text { The number of new products, the number of line } \\
\text { changes to fulfil international demand, and the fre- } \\
\text { quency of changes in products required by foreign mar- } \\
\text { kets }\end{array}$ \\
\hline & $\begin{array}{l}\text { Innovation in pro- } \\
\text { cesses }\end{array}$ & $\begin{array}{l}\text { Adaptations in administrative, technological, product, } \\
\text { and market processes to operate internationally }\end{array}$ \\
\hline & $\begin{array}{l}\text { Creativity to act in- } \\
\text { ternationally }\end{array}$ & Engagement and tests; external market experiments \\
\hline & $\begin{array}{l}\text { Differentiation by ex- } \\
\text { ternal market }\end{array}$ & $\begin{array}{l}\text { Initiatives of awkward imitation by international com- } \\
\text { petitors }\end{array}$ \\
\hline \multirow{4}{*}{ Risk-Taking } & General risk & $\begin{array}{l}\text { A strong trend to high-risk projects to attend external } \\
\text { markets }\end{array}$ \\
\hline & Decision risk & $\begin{array}{l}\text { Preference of managers to act with autonomy and per- } \\
\text { sonal risk assumption to explore external markets }\end{array}$ \\
\hline & Financial risk & Risk of financial loss or without the premium \\
\hline & $\begin{array}{l}\text { International Busi- } \\
\text { ness risk }\end{array}$ & Actions of large extent to counter business hostility \\
\hline \multirow{4}{*}{ Autonomy } & Team & $\begin{array}{l}\text { Leaders with autonomous behaviour that coordinate ac- } \\
\text { tivities with measures and international monitoring }\end{array}$ \\
\hline & Centralisation & Model management; decision and authority delegation \\
\hline & Accountability & $\begin{array}{l}\text { Participation in sectoral, consortia, or independent pro- } \\
\text { jects to promote external market prospection actions }\end{array}$ \\
\hline & $\begin{array}{l}\text { Organisational capac- } \\
\text { ity }\end{array}$ & $\begin{array}{l}\text { Departmental action or business units coordinated by } \\
\text { managers with entrepreneurial characteristics }\end{array}$ \\
\hline \multirow{4}{*}{$\begin{array}{l}\text { Competitive } \\
\text { Aggressiveness }\end{array}$} & $\begin{array}{l}\text { Reaction to competi- } \\
\text { tion }\end{array}$ & $\begin{array}{l}\text { Moving in reaction or with aggressive behaviour towards } \\
\text { competitors and changes in foreign markets }\end{array}$ \\
\hline & Financial competition & $\begin{array}{l}\text { Search for positioning to cash flow costs, profitability, } \\
\text { patents cost, licensing, and certifications }\end{array}$ \\
\hline & $\begin{array}{l}\text { International } \\
\text { Business competition }\end{array}$ & $\begin{array}{l}\text { Aggressiveness to confront trends of unfavourable } \\
\text { changes; imitation, copying, or use of unconventional } \\
\text { methods }\end{array}$ \\
\hline & Market positioning & $\begin{array}{l}\text { International marketing mix for new products, services, } \\
\text { distribution, and different markets }\end{array}$ \\
\hline
\end{tabular}

Source: own elaboration based on Amal and Freitag Filho (2010), Da Rocha et al. (2012), Leite and Moraes (2015), Martens et al. (2016). 


\section{MATERIAL AND METHODS}

To analyse IEO as an element of firms' strategy, the study design relied on the literature review (Flick, 2002) to detail the issue, assess data collection procedures, and examine and introduce information. The mooring matrix shows the steps to confirm the structure (Table 5).

Table 5. Mooring matrix

\begin{tabular}{|c|c|c|c|}
\hline Research Model & Theoretical Model & Operational Steps & Data Analysis \\
\hline $\begin{array}{l}\text { Identification of data- } \\
\text { bases and journals }\end{array}$ & \begin{tabular}{|l|} 
Database construction on \\
International Entrepre- \\
neurial Orientation \\
\end{tabular} & $\begin{array}{l}\text { Use of NVIVO program } \\
\text { for synthesis and con- } \\
\text { tent analysis }\end{array}$ & \multirow{2}{*}{$\begin{array}{l}\text { 1. Thematic analysis; } \\
\text { documentary and in- } \\
\text { depth interviews; } 2 \text {. } \\
\text { identification of simi- } \\
\text { larities and differ- } \\
\text { ences between or- } \\
\text { ganisations }\end{array}$} \\
\hline $\begin{array}{l}\text { Understanding of EO } \\
\text { structure in terms of } \\
\text { dimensions and cate- } \\
\text { gories }\end{array}$ & $\begin{array}{l}\text { Recognition of theories } \\
\text { in terms of authors and } \\
\text { articles available in the } \\
\text { literature }\end{array}$ & $\begin{array}{l}\text { Understanding pro } \\
\text { dures, formatting, } \\
\text { presenting EO con }\end{array}$ & \\
\hline $\begin{array}{l}\text { Confirmation of ele- } \\
\text { ments considered to } \\
\text { be managerial prac- } \\
\text { tises }\end{array}$ & $\begin{array}{l}\text { Review of the literature } \\
\text { and temporal situation of } \\
\text { theories }\end{array}$ & $\begin{array}{l}\text { Codification of relevant } \\
\text { dimensions and ele- } \\
\text { ments }\end{array}$ & $\begin{array}{l}\text { 1. In-depth inter- } \\
\text { views; } 2 \text {. Characteri- } \\
\text { sation of companies }\end{array}$ \\
\hline $\begin{array}{l}\text { Evaluation of the in- } \\
\text { ternational activities } \\
\text { of firms }\end{array}$ & $\begin{array}{l}\text { Exploration of conditions } \\
\text { and evaluation of current } \\
\text { concepts }\end{array}$ & $\begin{array}{l}\text { Systematisation and } \\
\text { evaluation of results }\end{array}$ & $\begin{array}{l}\text { Content and narra- } \\
\text { tive inquiry of inter- } \\
\text { views }\end{array}$ \\
\hline $\begin{array}{l}\text { Elaboration of the } \\
\text { multi-case study }\end{array}$ & $\begin{array}{l}\text { Understanding of con- } \\
\text { ceptual models }\end{array}$ & $\begin{array}{l}\text { Definition of the matrix } \\
\text { presentation }\end{array}$ & $\begin{array}{l}\text { Analysis of the multi- } \\
\text { case study }\end{array}$ \\
\hline
\end{tabular}

Source: own elaboration based on Flick (2002).

The literature search and selection stage utilised the databases CAPES-Periodicals, EBSCOhost, Elsevier Science Direct and Proquest libraries, to find direct citations. The corpus arrangement included searching through keywords like "internationalisation," "international entrepreneurship," "entrepreneurial orientation," "entrepreneurship," and searches for articles with titles containing "international entrepreneurial orientation." After locating relevant literature, the use of bibliographic and bibliometric reviews supported the creation of the resulting conference corpus for the study (Rauch et al., 2009; Jones et al., 2011; Martens et al., 2016). The majority of studies relied on EO constructs that used dependent variables of internationalisation theories and, mostly, quantitative methods. However, for the last 20 years, the field evolved to focus on international entrepreneurship (IE) as a way of examining internationalisation processes (Autio, 2017). Operationally, there still exists a continuing need for measurements to characterise IEO and the different types of resources and capabilities concerning the internationalisation of SMEs from Latin America (Bianchi, Glavas, \& Mathews, 2017).

The study follows Miller's (2011) proposition to apply qualitative methodologies to investigate entrepreneurial orientation in specific contexts. For the interpretation of the context of firms, a multiple case study generated several key organisational characteristics to facilitate comparison between the organisations (Doz, 2011). The population of the study consisted of companies' owners of four SMEs that export air sports products. The selected companies are critical cases as they represent almost all the industry in Brazil and 
differ in organisational aspects (Vissak, 2010). To address the matter of EO's expressions, the study employed two complementary approaches, the use of a computer-assisted qualitative data analysis software, as recognised by Covin and Wales (2012), and the use of a matrix represented by the firm's scores or profile across various dimensions (Polites, Roberts, \& Thatcher, 2012). Once the few informants restricted the possibility to triangulate qualitative data with other methods such as surveys, studies from Brazilian literature supported the development of the theoretical framework with meanings closer to the companies' context (Table 4). These individual informants reported data not on themselves but their organisations (Table 6).

To assert the frequency of words as indicative of the strength of IEO's dimensions in those companies, the use of NVIVO offered comprehensive support for the content analysis and interpretation of the narratives found in multiple documents and in-depth interviews. This strategy followed the two-phased procedure suggested by McKenny, Aguinis, Short, \& Anglin (2016) when acknowledging the validity and reliability of the computer-assisted qualitative analysis of entrepreneurial orientation constructs. First, the selected papers were open coded for preliminary content analysis to distinguish the topics. More specifically about the codification phase, the EO dimensions reflected the elements that comprise business practises in the companies; and the concept served for profile construct to help the researcher understand the phenomena under investigation (Bazeley \& Jackson, 2013; Paulus et al., 2017). After outlining the dimensions, a list of words supported the interpretation of the entrepreneurs' narratives. The collection of words was favoured by The Blackwell Encyclopedia of Management: Entrepreneurship, as proposed by Short et al. (2010). Moreover, for final delivery, the software's tools for word frequency analysis - text coding and matrix coding - facilitated the presentation of crossings and interrelations between the data and the narrative offered by the companies' owners (Lage, 2011).

Regarding the questionnaire (Dess \& Lumpkin, 2005, p.153), translated questions and the context of the construct followed the consolidation provided by Freitas et al. (2012). In this respect, one first interview assessed the commentaries of an independent commercial agent for the same national air sports sector. Overall, the use of protocols in the form of a semi-structured questionnaire - with reports and webpages verifications - conformed to an interactive exercise between the researcher and informants, as the four in-depth interviews provided a useful way to learn about their companies' characteristics (Vissak, 2010). Visits for data collection phase started right after the reception of consent, whereas vis-à-vis interviews occurred at respective company establishments from March to August of 2017. The recording of interviews took about 90 minutes and resulted in unique reports for each company. The entrepreneurs received transcriptions for confirmation and revised the texts from June to October of 2017. The revisions counted with each entrepreneur's voice and knowledge for improving the interpretation and naming of practises, to refine and relate elements to themes. Final reports validated the owner's narrative with the content found in the literature (Paulus et al., 2017).

In terms of EO's measurement, scholars point to fundamental differences like the dimensions that form the core EO construct (Covin \& Wales, 2012; Anderson et al., 2015). However, the study addresses the difficulty of determining the structure of a multidimensional construct by theorising different profile constructs to exist at the 
same level of dimensions and to represent the influence of each one (Polites et al., 2012). Divided into a series of discrete levels, the profiles facilitated the visualisation of various combinations of IEO levels (Table 7). Thus, each observation in the firm's scores measured as the distance from the best profile member in the matrix, evidenced each dimension points about the average of all the data classified under the general profile (McKenny et al., 2016).

\section{RESULTS AND DISCUSSION}

To accomplish the primary objective and answer the research question, this research assessed the methodological aspects of IEO literature and contextualised the profile frames to discuss the implications found in the results. The studied companies share specific industry characteristics, as they utilise niche strategies in markets worldwide. The following tables demonstrate the characteristics of the companies (Table 6), and the expected IEO posture (Table 7) found in the study. Hence, the profiling of their cross-border operations exhibited common aspects that may have influenced the acquisition of operational attributes required by the company's strategic orientation (Magnani \& Zucchella, 2019).

First, to characterise SMEs internationalisation in emerging economies (Kazlauskaitè et al., 2015), the companies were grouped in Table 6 according to a series of indicators (Dib, Da Rocha \& Silva, 2010; Da Rocha et al., 2012). For example, establishment before 1990 (Rotor Harnesses and Trike Icaros) and after 1990 (Sol Paragliders and Tirante A). This differentiation makes sense from a theoretical perspective, but also from the viewpoint of these firms' evolution in international market knowledge and technological expertise. Not only did the younger group take much less time to export but they also developed more products and exported to more countries. The informants often referred to the need of certifications: "equipment produced within strict aeronautical standards" (Trike Icaros); but they express less need for patents: "several people have already copied my products, as I have copied as well, it makes me innovate more" (Rotor Harnesses); "yes, being imitated is good. Even more so in our business today. When we present a paraglider to the market; everything in that paraglider is already tested" (Sol Paragliders).

There are examples of reputation and social capital as drivers of internationalisation (Tang, 2011) like the two companies with higher exports rates. For the Rotor Harnesses owner, "the foreign market helped develop the domestic market. After the Brazilian team won the world championship in Italy, everything changed." For the Sol Paragliders owner, "for the 18th time in a row, we were present at the largest free-flight event in the world at Saint Hilaire, France." There are examples of resource constraints and intermittent innovative actions (Zonta \& Amal, 2018). Trike Icaros owner mentioned: "the customers contact us via the website, email, and social group lists; we do not invest in roadshows outside Brazil." Whereas, Tirante A owner explained: "the first time we visited a fair, only two other companies held expositions. The second time, many others appeared. Manufacturers started popping up worldwide, so we stopped visiting fairs.

The classification by the NVIVO coding matrix enabled the examination and exploration of data across and within categories, allowing for comparisons between the collected material and general overview of companies' managerial practises (Table 7). 
Table 6. Characteristics of air sport companies

\begin{tabular}{|l|l|l|l|l|}
\hline Characteristics & \multicolumn{1}{|c|}{ Rotor Harnesses } & \multicolumn{1}{|c|}{ Trike Icaros } & \multicolumn{1}{|c|}{ Sol Paragliders } & \multicolumn{1}{|c|}{ Tirante A } \\
\hline Scope & 10 countries & 5 countries & 56 countries & 15 countries \\
\hline Products & $\begin{array}{l}\text { 5+ models of har- } \\
\text { nesses and prod- } \\
\text { ucts for hang glid- } \\
\text { ers }\end{array}$ & $\begin{array}{l}\text { 18 combinations } \\
\text { of trikes and mi- } \\
\text { crolight aircrafts }\end{array}$ & $\begin{array}{l}\text { 60+ general prod- } \\
\text { ucts for paragliders }\end{array}$ & $\begin{array}{l}\text { 4 electronic } \\
\text { products }\end{array}$ \\
\hline Established & 1983 & 1986 & 1991 & 2009 \\
\hline Marketing & $\begin{array}{l}\text { Promotion, af- } \\
\text { tersales, and spon- } \\
\text { sorship }\end{array}$ & $\begin{array}{l}\text { Online promo- } \\
\text { tion }\end{array}$ & $\begin{array}{l}\text { Trade fairs, promo- } \\
\text { tions, sponsorships, } \\
\text { online shop }\end{array}$ & Business trips \\
\hline First Export & 15 years after & 17 years after & 2 years after & 1 year after \\
\hline Entry Mode & $\begin{array}{l}\text { Representation, in- } \\
\text { direct exports }\end{array}$ & $\begin{array}{l}\text { Representation, } \\
\text { direct exports }\end{array}$ & $\begin{array}{l}\text { Representation, di- } \\
\text { rect exports }\end{array}$ & $\begin{array}{l}\text { Dealers only, } \\
\text { indirect exports }\end{array}$ \\
\hline $\begin{array}{l}\text { Reason to Partici- } \\
\text { pate in Interna- } \\
\text { tional Markets }\end{array}$ & $\begin{array}{l}\text { Innovation, part- } \\
\text { nerships, certifica- } \\
\text { tion, and branding }\end{array}$ & Distribution & $\begin{array}{l}\text { Innovation, partner- } \\
\text { ships, certification, } \\
\text { and branding }\end{array}$ & Distribution \\
\hline Size & 4 persons & 5 persons & 150+ persons & 5 persons \\
\hline Relevance & $85 \%$ exports & 25\% exports & 50\% exports & $15 \%$ exports \\
\hline
\end{tabular}

Source: own elaboration based on Dib et al. (2010) and Da Rocha et al. (2012).

After word frequency assessment and converting coverage percentages into points, the latter facilitated the understanding of the influence of each of the five dimensions ranged 37-51 points, with an average of 43 points. According to the report, the evolution of elements shows that the dimension of proactivity (51) stands out with the highest number of highlighted elements. The dimensions of Innovation (44), risk assumption (44), and autonomy (41) had several attenuated categories with organisations presenting variation among the elements. Competitive aggressiveness (37) emerges with the least number of attenuated elements. Interestingly, the dimension of autonomy appears with the most significant disparity, which suggests that companies practise it less homogeneously. Similarly, the individual scores of companies ranged 46-68 points, with an average of 54 points. Sol Paragliders (68) presented the highest levels of innovation (16), proactivity (15), autonomy (13), competitive aggressiveness (13), and risk-taking (11). The second company, Trike Icaros (52), emerged as almost equally proactive (14) but more balanced among innovation, autonomy, and risk-taking (10), with less competitive aggressiveness (8). Subsequently, the third company was Tirante A (51), which presented the highest level of risk-taking (16), followed by proactivity (10), innovation (9), autonomy (8), and competitive aggressiveness (8). The company with least intensity in total, Rotor Harnesses (46), appeared as more consistent among the five dimensions: proactivity (12), autonomy (10), innovation (9), competitive aggressiveness (8), and risktaking (7). In general, the discrepancies between autonomy and competitive aggressiveness seem to explain reasonably well the difference in internationalisation pathways of the SMEs, even though there is inherent innovativeness, risk-taking, and proactiveness in all of the measures of managerial elements. 
Table 7. IEO in air sport companies

\begin{tabular}{|c|c|c|c|c|c|}
\hline \multirow[b]{2}{*}{ Dimensions } & \multicolumn{5}{|c|}{ Management Elements } \\
\hline & Categories & $\begin{array}{l}\text { Rotor Har- } \\
\text { nesses: } 46\end{array}$ & $\begin{array}{l}\text { Tirante A: } \\
\quad 51\end{array}$ & $\begin{array}{l}\text { Trike Ica- } \\
\text { ros: } 52\end{array}$ & $\begin{array}{l}\text { Sol Para- } \\
\text { gliders: } 68\end{array}$ \\
\hline \multirow{4}{*}{ Proactivity: 51} & Adaptability/Flexibility: 14 & 3 & 3 & 4 & 4 \\
\hline & Anticipation: 13 & 3 & 3 & 4 & 3 \\
\hline & Troubleshooting: 13 & 3 & 2 & 4 & 4 \\
\hline & Monitoring: 11 & 3 & 2 & 2 & 4 \\
\hline \multirow{4}{*}{ Innovation: 44} & $\begin{array}{l}\text { Products for the external } \\
\text { market: } 13\end{array}$ & 3 & 3 & 3 & 4 \\
\hline & Innovation in processes: 11 & 2 & 2 & 3 & 4 \\
\hline & $\begin{array}{l}\text { Creativity to act internation- } \\
\text { ally: } 10\end{array}$ & 2 & 2 & 2 & 4 \\
\hline & $\begin{array}{l}\text { Differentiation by external } \\
\text { market: } 10\end{array}$ & 2 & 2 & 2 & 4 \\
\hline \multirow{4}{*}{ Risk-Taking: 44} & General risk: 15 & 3 & 4 & 4 & 4 \\
\hline & Decision risk: 12 & 2 & 4 & 3 & 3 \\
\hline & Financial risk: 9 & 1 & 4 & 2 & 2 \\
\hline & International Business risk: 8 & 1 & 4 & 1 & 2 \\
\hline \multirow{4}{*}{ Autonomy: 41} & Centralization: 16 & 4 & 4 & 4 & 4 \\
\hline & Accountability: 12 & 4 & 2 & 4 & 2 \\
\hline & Organizational capacity: 7 & 1 & 1 & 1 & 4 \\
\hline & Team: 6 & 1 & 1 & 1 & 3 \\
\hline \multirow{4}{*}{$\begin{array}{l}\text { Competitive } \\
\text { Aggressiviness: } \\
37\end{array}$} & $\begin{array}{l}\text { International Business com- } \\
\text { petition: } 11\end{array}$ & 2 & 3 & 2 & 4 \\
\hline & Reaction to Competition: 9 & 2 & 2 & 2 & 3 \\
\hline & Market positioning: 9 & 2 & 2 & 1 & 4 \\
\hline & Financial Competition: 8 & 2 & 1 & 3 & 2 \\
\hline
\end{tabular}

1) white cells = categories not mentioned; 2 ) light grey cells = categories mentioned less frequently; 3 ) grey cells = categories with low occurrence; 4 ) dark cells = categories with high occurrence.

Source: own study.

Within a specific and nascent industry context, the perspective of IEO referred to internationalisation as critical to air sports companies based in Brazil, which allows us to identify patterns employed as strategic orientations that stimulate firm-level processes for new entries onto international markets, regardless of firm's size, age, or capabilities. When conceived as a posture-based phenomenon, the concept favours competitive actions of firms to move into new product-market arenas. For example, Tirante A displayed the most evident risk-taking intensity combined with low competitive aggressiveness disposition. Even though Tirante A stopped exporting, the knowledge accumulated in international business helped it to foster their viability in other markets and segments. Noteworthy, in terms generalizability (Wales et al., 2019), the dimension of autonomy offered a less accurate representation of what it means for firms to be entrepreneurially oriented within such a distinct socio-cultural context. The findings evidence that the firms leverage this capacity at lower levels. Results show that the entrepreneurs, in this case, confuse this organisational factor with centralisation and the lack of accountability processes. 


\section{Further Discussion}

The following is a brief overview of each dimension, along with the category that mostly reflected the practises employed by the companies, accompanied by a short transcription of two most disparate reports.

PROACTIVITY (adaptability and flexibility): expanding a firm's operations assumed as reflections of company adaptability and reinvestment capacities as industry requirements (Żur, 2015).

"Today we understand that the market is segmenting, the new developments you see, one, two... fourteen canopies, plus the prototype, is to serve the same market size as five years ago we were serving with half the number of models" (Sol Paragliders).

"The products have one point in common, which is technology. So, a lot of the technology we created for air sports, we use here today in another segment (fleet control), now we need to adapt to this new customer, create a distribution, grow management, not just the product anymore" (Tirante A).

INNOVATION (products for external markets): treated as the potential for new market entries, it also is a source of learning experience when one considers certifications, participation in international fairs, import/export modes, or foreign personnel cooperation (Kosala, 2015).

"We created more than 40 products since 2000, when we brought Andre (designer) from Switzerland; he already had a vast experience. We started with competition wings that served as prototypes for intermediary levels and further certifications. In two years, we already had a product mix equal to our European competitors" (Sol Paragliders).

"When the [delta-wing] factory started to represent me, we already had novel features but a small line of products. To meet the basic need of safety in parachute opening, I invested in processes, modelling, new equipment, and soon after we also certified the equipment with the help of our German representative. It was a learning process for me at the time, a complicated one" (Rotor Harnesses).

RISK TAKING (general risk): the lack of planning for risk management at various levels of a network, business level or functional level along with the increasing speed of the process of internationalisation (Fudaliński, 2015).

"The risk is greater. Whenever you export and present the product, if you have a problem, it is much more complicated for you to solve. We had a case in Korea that was not cool. We sent the variometre and - due to a mistake in the production here the 1500 model received the software of the TAV1000. It was a loss to solve the problem and such image crisis" (Tirante A).

"When I was sewing alone, I took many risks without representatives; you are at a disadvantaged situation, because either you have to send another product to the customer or the customer gives up the sale and you lose money. As the business is tailor-made, in the beginning, many pieces were stranded, returned, and such; we encountered first acceptance problems" (Rotor Harnesses).

AUTONOMY (centralisation): structural autonomy as necessary to obtain an employee's creativity (Freitas et al., 2012).

"Here, $20 \%$ of people are pilots involved with the factory, design, and administration. About the commercial department today we have people dedicated to international 
trade, people who speak languages, do all the contacts with the markets, but it depends on the dynamics of the company; before 2004, I did everything with my brother and a few representatives"(Sol Paragliders).

"My daughter is responsible for the commercial area, financial, purchasing, and sales. She is the first contact the client gets, she is the person who orders the budget and checks if the client received the product. If I realise the client has cooled in the negotiation because he is more interested in the technical area, I take part in communication, even though she is a pilot as well. We do not have an international department; it is our representatives who take care of the export" (Trike Icaros).

COMPETITIVE AGGRESSIVENESS (international business competition): as a response to the actions of the competition, firms need enhanced monitoring capabilities (Hughes-Morgan, Kolev, \& Mcnamara, 2018).

"There was always something exciting in Germany, which until today makes it difficult to sell through schools. If a school sells specific brands, another school sells the same brands too. I want to pull one of those brands for myself. Therefore, the same way we find in Brazil new entrants sending directly their products via parcel to the consumer's house, this practice only does damage. If everyone gives a three-month warranty, I provide six months to double the warranty time" (Sol Paragliders);

"The competition is for relationships, so the guy who sells Sol already knows the Brazilian product and has no objections to the product. We surfed a little on the wave that already existed! We contacted representatives mainly via Skype and email. We visited these people at schools all around Europe. Then we went to a fair in France to share the booth with Sol, we even exported to South Korea and Iraq" (Tirante A).

Although differentiation has to do with innovations that are difficult to imitate, the analysis shows that the sector follows imitation practises. According to IEO literature, the influence of autonomy on firm performance is complex, as organisational and international marketing approaches can provide insights into when the dimension is a critical driver of firm performance across international contexts. We would propose that the effects of autonomy on companies' outcomes are positively associated with international cultural contexts and international marketing adaptation. Even with significant differences in age, size, or the existence of specialised departments among companies, the possible implications for the IEO construct are that resources such as reputation, different licenses, and certifications are competitive advantages that encourage internationalisation processes as a means of forceful entry and continuous development.

\section{CONCLUSIONS}

The main goal of this research was to explore to what extent international entrepreneurial orientation (IEO) appears in internationalisation strategies developed by SMEs exporting from emerging markets. The concept of IEO proved useful for monitoring the environment and forecasting the competitor's actions in international business. The dimensions of IEO conform to evidence that managerial elements enhanced the companies' international experience and reflected in the internal organisation of studied firms. Further research would be valuable for the identification of elements and categories of IEO in other economic sectors. Attention to other approaches that include quantitative data may relate to 
a more analytical capacity on a more adequate and updated conceptual basis in later studies. Limitations related to the scales used and data collected in the above discussion are that the study investigated only Brazilian companies from the same industry. A more significant number of participants from different industries in international markets would favour generalisation and theory development. Future research can investigate concepts of co-creation to bring new insights into the international development of companies to distinguish how entrepreneurial organisations with autonomy constraints succeed by showing competitive aggressiveness, as critical determinants to entering new foreign markets with innovative products.

\section{REFERENCES}

Alvarez, S.A., \& Barney, J.B. (2017). Resource-based theory and the entrepreneurial firm. Strategic Entrepreneurship: Creating a New Mindset, 87-105. https://doi.org/10.1002/9781405164085.ch5

Amal, M., \& Freitag Filho, A.R. (2010). Internationalization of small and medium-sized enter-prises: a multi-case study. European Business Review, 22(6), 608-623. https://doi.org/10.1108/09555341011082916

Anderson, B.S., Kreiser, P.M., Kuratko, D.F., Hornsby, J.S., \& Eshima, Y. (2015). Reconceptualizing entrepreneurial orientation. Strategic Management Journal, 36(10), 1579-1596. https://doi.org/10.1002/smj.2298

Autio, E. (2017). Strategic entrepreneurial internationalization: A normative framework. Strategic Entrepreneurship Journal, 11(3), 211-227. https://doi.org/10.1002/sej.1261

Bazeley, P., \& Jackson, K. (Eds.). (2013). Qualitative data analysis with NVivo. London: Sage Publications.

Bianchi, C., Glavas, C., \& Mathews, S. (2017). SME international performance in Latin America: The role of entrepreneurial and technological capabilities. Journal of Small Business and Enterprise Development, 24(1), 176-195. https://doi.org/10.1108/JSBED-09-2016-0142

Birkinshaw, J., \& Gupta, K. (2013). Clarifying the distinctive contribution of ambidexterity to the field of organization studies. Academy of Management Perspectives, 27(4), 287-298. https://doi.org/10.5465/amp.2012.0167

Boso, N., Oghazi, P., \& Hultman, M. (2017). International entrepreneurial orientation and regional expansion. Entrepreneurship and Regional Development, 29(1-2), 4-26. https://doi.org/10.1080/08985626.2016.1255430

Carneiro, J., \& Brenes, E.R. (2014). Latin American firms competing in the global economy. Journal of Business Research, 67(5), 831-836. https://doi.org/10.1016/j.jbusres.2013.07.001

Coviello, N.E., McDougall, P.P., \& Oviatt, B.M. (2011). The emergence, advance and future of international entrepreneurship research-an introduction to the special forum. Journal of Business Venturing, 26(6), 625-631. https://doi.org/10.1016/j.jbusvent.2011.07.002

Covin, J.G., \& Lumpkin, G.T. (2011). Entrepreneurial orientation theory and research: Reflections on a needed construct. Entrepreneurship Theory and Practice, 35(5), 855-872. https://doi.org/10.1111/j.1540-6520.2011.00482.x

Covin, J.G., \& Miller, D. (2014). International entrepreneurial orientation: Conceptual considerations, research themes, measurement issues, and future research directions. Entrepreneurship Theory and Practice, 38(1), 11-44. https://doi.org/10.1111/etap.12027

Covin, J.G., \& Slevin, D.P. (1989). Strategic management of small firms in hostile and benign environments. Strategic Management Journal, 10(1), 75-87. https://doi.org/10.1002/smj.4250100107 
Covin, J.G., \& Wales, W.J. (2012). The measurement of entrepreneurial orientation. Entrepreneurship Theory and Practice, 36(4), 677-702. https://doi.org/10.1111/j.1540-6520.2010.00432.x

Covin, J.G., \& Wales, W.J. (2019). Crafting high-impact entrepreneurial orientation research: Some suggested guidelines. Entrepreneurship Theory and Practice, 43(1), 3-18. https://doi.org/10.1177/1042258718773181

Da Rocha, A., Mello, R.C., Pacheco, H., \& Farias, I.A. (2012). The international commitment of lateinternationalizing Brazilian entrepreneurial firms. International Marketing Review, 29(3), 228252. https://doi.org/10.1108/02651331211229741

Dai, L., Maksimov, V., Gilbert, B.A., \& Fernhaber, S.A. (2014). Entrepreneurial orientation and international scope: The differential roles of innovativeness, proactiveness, and risk-taking. Journal of Business Venturing, 29(4), 511-524. https://doi.org/10.1016/j.jbusvent.2013.07.004

Dess, G.G., \& Lumpkin, G.T. (2005). The role of entrepreneurial orientation in stimulating effective corporate entrepreneurship. Academy of Management Perspectives, 19(1), 147-156. https://doi.org/10.5465/ame.2005.15841975

Dib, L.A., Da Rocha, A., \& Silva, J.F. (2010). The internationalization process of Brazilian software firms and the born global phenomenon: Examining firm, network, and entrepreneur variables. Journal of International Entrepreneurship, 8(3), 233-253. https://doi.org/10.1007/s10843-010-0044-z

Doz, Y. (2011). Qualitative research for international business. Journal of International Business Studies, 42(5), 582-590. https://doi.org/10.1057/jibs.2011.18

Etemad, H. (2019). Revisiting interactions of entrepreneurial, marketing, and other orientations with internationalization strategies. Journal of International Entrepreneurship, 17(1), 1-18. https://doi.org/10.1007/s10843-019-00243-6

Flick, U. (2002). Qualitative research-state of the art. Social Science Information, 41(1), 5-24. https://doi.org/10.1177/0539018402041001001

Freeman, S., \& Cavusgil, S.T. (2007). Toward a typology of commitment states among managers of born-global firms: A study of accelerated internationalization. Journal of International Marketing, 15(4), 1-40. https://doi.org/10.1509/jimk.15.4.1

Freitas, H., Martens, C.D.P., Boissin, J.P., \& Behr, A. (2012). Guidance elements for the entrepreneurial orientation of software firms. Revista de Administração (São Paulo), 47(2), 163-179. https://doi.org/10.5700/rausp1032

Fudaliński, J. (2015). Risk-taking propensity and firm internationalisation process. Entrepreneurial Business and Economics Review, 3(2), 85-104. https://doi.org/10.15678/EBER.2015.030207

Hughes-Morgan, M., Kolev, K., \& Mcnamara, G. (2018). A meta-analytic review of competitive aggressiveness research. Journal of Business Research, 85, 73-82. https://doi.org/10.1016/j.jbusres.2017.10.053

Jones, M.V., \& Coviello, N.E. (2005). Internationalisation: conceptualising an entrepreneurial process of behaviour in time. Journal of International Business Studies, 36(3), 284-303. https://doi.org/10.1057/palgrave.jibs.8400138

Jones, M.V., Coviello, N., \& Tang, Y.K. (2011). International entrepreneurship research (1989-2009): a domain ontology and thematic analysis. Journal of Business Venturing, 26(6), 632-659. https://doi.org/10.1016/j.jbusvent.2011.04.001

Kazlauskaitè, R., Autio, E., Gelbūda, M., \& Šarapovas, T. (2015). The Resource-based View and SME Internationalisation: An Emerging Economy Perspective. Entrepreneurial Business and Economics Review, 3(2), 53-64. https:/doi.org/10.15678/EBER.2015.030205

Knight, G.A. (2001). Entrepreneurship and strategy in the international SME. Journal of international management, 7(3), 155-171. https://doi.org/10.1016/S1075-4253 (01)00042-4 
Knight, G.A., \& Cavusgil, S.T. (2005). A taxonomy of born-global firms. MIR: Management International Review, 15-35. Retrieved from www.jstor.org/stable/40836141 on July 15, 2019.

Knight, G.A., \& Kim, D. (2009). International business competence and the contemporary firm. Journal of International Business Studies, 40(2), 255-273. https://doi.org/10.1057/palgrave.jibs. 8400397

Kosala, M. (2015). Innovation processes as a stimulant of internationalisation process of firms. Entrepreneurial Business and Economics Review, 3(2), 65-84. https://doi.org/10.15678/EBER.2015.030206

Kozlenkova, I.V., Samaha, S.A., \& Palmatier, R.W. (2014). Resource-based theory in marketing. Journal of the Academy of Marketing Science, 42(1), 1-21. https://doi.org/10.1007/s11747-013-0336-7

Kuivalainen, O., Sundqvist, S., Saarenketo, S., \& McNaughton, R. (2012). Internationalization patterns of small and medium-sized enterprises. International Marketing Review, 29(5), 448-465. https://doi.org/10.1108/02651331211260331

Lage, M.C. (2011). Utilização do software NVivo em pesquisa qualitativa: uma experiência em EaD. ETD-Educação Temática Digital, 12(esp.), 198-226. https://doi.org/10.20396/etd.v12i0.1210

Leite, Y.V.P., \& de Moraes, W.F.A. (2015). The ability to innovate in international entrepreneur-ship. Revista de Administração, 50(4), 447-459. https://doi.org/10.5700/rausp1212

Lisboa, A., Skarmeas, D., \& Lages, C. (2011). Entrepreneurial orientation, exploitative and explorative capabilities, and performance outcomes in export markets: A resource-based approach. Industrial Marketing Management, 40(8), 1274-1284. https://doi.org/10.1016/j.indmarman.2011.10.013

Lumpkin, G.T., \& Dess, G.G. (1996). Clarifying the entrepreneurial orientation construct and linking it to performance. Academy of Management Review, 21(1), 135-172. https://doi.org/10.5465/amr.1996.9602161568

McKenny, A.F., Aguinis, H., Short, J.C., \& Anglin, A.H. (2016). What doesn't get measured does exist: Measuring measurement error in computer-aided text analysis. Journal of Management. https://doi.org/10.1177/0149206316657594

Magnani, G., \& Zucchella, A. (2019). Coping with uncertainty in the internationalisation strategy: An exploratory study on entrepreneurial firms. International Marketing Review, 36(1), 131-163. https://doi.org/10.1108/IMR-02-2017-0042

Martens, C.D.P., Lacerda, F.M., Belfort, A.C., \& Freitas, H.M.R.D. (2016). Research on entrepreneurial orientation: current status and future agenda. International Journal of Entrepreneurial Behavior \& Research, 22(4), 556-583. https://doi.org/10.1108/IJEBR-08-2015-0183

Martin, S.L., \& Javalgi, R.R.G. (2016). Entrepreneurial orientation, marketing capabilities and performance: the moderating role of competitive intensity on Latin American International new ventures. Journal of Business Research, 69(6), 2040-2051. https://doi.org/10.1016/j.jbusres.2015.10.149

Miller, D. (2011). Miller (1983) revisited: A reflection on EO research and some suggestions for the future. Entrepreneurship Theory and Practice, 35(5), 873-894. https://doi.org/10.1111/j.15406520.2011.00457.x

Miller, D. (2018). Challenging trends in configuration research: Where are the configurations?. Strategic Organization, 16(4), 453-469. https://doi.org/10.1177/1476127017729315

Paulus, T., Woods, M., Atkins, D.P., \& Macklin, R. (2017). The discourse of QDAS: Reporting practices of ATLAS.ti and NVivo users with implications for best practices. International Journal of Social Research Methodology, 20(1), 35-47. https://doi.org/10.1080/13645579.2015.1102454

Polites, G.L., Roberts, N., \& Thatcher, J. (2012). Conceptualizing models using multidimensional constructs: a review and guidelines for their use. European Journal of Information Systems, 21(1), 22-48. https://doi.org/10.1057/ejis.2011.10 
Rauch, A., Wiklund, J., Lumpkin, G.T., \& Frese, M. (2009). Entrepreneurial orientation and business performance: An assessment of past research and suggestions for the future. Entrepreneurship Theory and Practice, 33(3), 761-787. https://doi.org/10.1111/j.1540-6520.2009.00308.x

Rialp, A., Rialp, J., \& Knight, G. (2015). International entrepreneurship: a review and future directions. In S.A. Fernhaber \& S. Prashantham (Eds.), The Routledge Companion to International Entrepreneurship (pp. 7-28). Abingdon: Routledge.

Sapienza, H.J., Autio, E., George, G. \& Zahra, S.A. (2006). A capabilities perspective on the effects of early internationalization on firm survival and growth. Academy of Management Review, 31(4), 914-933. https://doi.org/10.5465/amr.2006.22527465

Short, J.C., Broberg, J.C., Cogliser, C.C., \& Brigham, K.H. (2010). Construct validation using computeraided text analysis (CATA) an illustration using entrepreneurial orientation. Organizational Research Methods, 13(2), 320-347. https://doi.org/10.1177/1094428109335949

Slevin, D.P., \& Terjesen, S.A. (2011). Entrepreneurial orientation: Reviewing three papers and implications for further theoretical and methodological development. Entrepreneurship Theory and Practice, 35(5), 973-987. https://doi.org/10.1111/j.1540-6520.2011.00483.x

Sundqvist, S., Kyläheiko, K., Kuivalainen, O., \& Cadogan, J.W. (2012). Kirznerian and Schumpeterian entrepreneurial-oriented behavior in turbulent export markets. International Marketing Review, 29(2), 203-219. https://doi.org/10.1108/02651331211216989

Swoboda, B., \& Olejnik, E. (2016). Linking Processes and Dynamic Capabilities of International SMEs: The Mediating Effect of International Entrepreneurial Orientation. Journal of Small Business Management, 54(1), 139-161. https://doi.org/10.1111/jsbm.12135

Tang, Y.K. (2011). The Influence of networking on the internationalization of SMEs: Evidence from internationalized Chinese firms. International Small Business Journal, 29(4), 374-398. https://doi.org/10.1177/0266242610369748

Teece, D., Peteraf, M., \& Leih, S. (2016). Dynamic capabilities and organizational agility: Risk, uncertainty, and strategy in the innovation economy. California Management Review, 58(4), 13-35. http://dx.doi.org/10.1016/j. euroecorev.2015.11.006i

Tonial, G., \& Rossetto, C.R. (2017). International entrepreneurial orientation: the case of wineries participating in the Wines of Brazil Project. Journal of Business, 9(1), 23-42. https://doi.org/10.21678/jb.2017.821

Vissak, T. (2010). Recommendations for using the case study method in international business research. The Qualitative Report, 15(2), 370-388.

Wach, K. (2015). Entrepreneurial orientation and business internationalisation process: The theoretical foundations of international entrepreneurship. Entrepreneurial Business and Economics Review, 3(2), 9-24. https://doi.org/10.15678/EBER.2015.030202

Wales, W.J. (2016). Entrepreneurial orientation: A review and synthesis of promising research directions. International Small Business Journal, 34(1), 3-15. https://doi.org/10.1177/0266242615613840

Wales, W., Gupta, V.K., Marino, L., \& Shirokova, G. (2019). Entrepreneurial orientation: International, global and cross-cultural research. International Small Business Journal, 37(2), 95-104. https://doi.org/10.1177/0266242618813423

Wales, W., Monsen, E., \& McKelvie, A. (2011). The organizational pervasiveness of entrepreneurial orientation. Entrepreneurship Theory and Practice, 35(5), 895-923. https://doi.org/10.1111/j.1540-6520.2011.00451.x

Wiklund, J., \& Shepherd, D. (2005). Entrepreneurial orientation and small business performance: a configurational approach. Journal of Business Venturing, 20(1), 71-91. https://doi.org/10.1016/j.jbusvent.2004.01.001 
Wiklund, J., \& Shepherd, D.A. (2011). Where to from here? EO-as-experimentation, failure, and distribution of outcomes. Entrepreneurship Theory and Practice, 35(5), 925-946. https://doi.org/10.1111/j.1540-6520.2011.00454.x

Zahra, S.A., Wright, M., \& Abdelgawad, S.G. (2014). Contextualization and the advancement of entrepreneurship research. International Small Business Journal, 32(5), 479-500. https://doi.org/10.1177/0266242613519807

Zonta, T.C., \& Amal, M. (2018). Internationalization and innovation: The case of a born global from Brazil. Internext: Revista Electrônica de Negócios Internacionais da ESPM, 13(1). https://doi.org/10.18568/1980-4865.13163-76

Żur, A. (2015). Opportunity Identification and Creation as Factors of Firm Internationalisation. Entrepreneurial Business and Economics Review, 3(2), 25-39. https://doi.org/10.15678/EBER.2015.030203 


\section{Authors}

The contribution of co-authors can be expressed as $90 \%$ and $10 \%$, respectively: R. Raats prepared the design, analysis and interpretation of data, methods, and literature review, while P. Krakauer supervised the work and did a final revision.

\section{Ricardo Raats}

PhD candidate in business administration (Tallinn University of Technology, Estonia). Master of Science in business administration (UNIFACCAMP, Brazil). His research interests include internationalisation and social entrepreneurship.

Correspondence to: Ricardo Ferraz Raats, Early Researcher, Tallinn University of Technology, School of Business and Governance, Ehitajate tee 5, 19086 Tallinn, Estonia, e-mail: ricardo.ferraz@taltech.ee ORCID () http://orcid.org/0000-0001-6151-7116

\section{Patrícia Viveiros de Castro Krakauer}

Professor at Centro Universitário Campo Limpo Paulista (UNIFACCAMP, Brazil). Her research interests include entrepreneurship education and entrepreneurial behaviour.

Correspondence to: Rua Guatemala, 167, prédio 8, Jardim América, 13231-230 Campo Limpo Paulista, Brazil, e-mail: patricia.krakauer@faccamp.br

ORCID (1) http://orcid.org/0000-0003-4262-1297

\section{Acknowledgements and Financial Disclosure}

We would like to thank anonymous reviewers for their valuable contribution and insights, as well as the editorial board for accepting the work.

\section{Copyright and License}

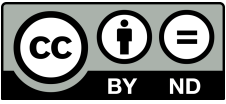

This article is published under the terms of the Creative Commons

Attribution - NoDerivs (CC BY-ND 4.0) License http://creativecommons.org/licenses/by-nd/4.0/

Published by the Centre for Strategic and International Entrepreneurship - Krakow, Poland 
